\title{
Asuhan Keperawatan Pada Ny.S dengan Gangguan Sistem Muskuloskeletal Post Op Orif Hari Ke-1 Akibat Fraktur Femur Sinistra 1/3 Proximal Complate
}

\author{
R. Deni Indrawan ${ }^{1 *}$, Septia Nur Hikmawati ${ }^{2}$ \\ Akademi Keperawatan Buntet Pesantren Cirebon, Indonesia ${ }^{1,2}$ \\ deniindrawancrb@gmail.com ${ }^{1 *}$, tiaseptianurhikmawati@gmail.com ${ }^{2}$
}

Received: 27-09-2021

Revised : 19-10-2021

Accepted: 21-10-2021

\begin{abstract}
Abstrak
Latar Belakang: Fraktur femur adalah rusaknya kontinuitas tulang pangkal paha yang dapat terjadi akibat trauma langsung maupun trauma tidak langsung. Indonesia menduduki peringkat kedelapan di Asia Tenggara dengan fraktur akibat kecelakaan lalu lintas. Kasus fraktur femur merupakan yang paling sering yaitu sebesar 39\% diikuti fraktur humerus (15\%), fraktur tibia dan fibula (11\%), dimana penyebab terbesar fraktur femur adalah kecelakaan lalu lintas yang biasanya disebabkan oleh kecelekaan mobil, motor, atau kendaraan rekreasi $(62,6 \%)$ dan jatuh dari ketinggian $(37,3 \%)$ dan mayoritas adalah pria $(63,8 \%)$.

Tujuan: Penelitian ini bertujuan untuk mampu melaksanakan asuhan keperawatan pada klien dengan gangguan sistem muskuloskeletal akibat post operasi orif fraktur femur sinistra $1 / 3$ proximal complate secara langsung dan komprehensif meliputi aspek bio-psiko-sosial dan spiritual dengan pendekatan proses keperawatan.
\end{abstract}

Metode: Penelitian ini menggunakan metode deskriptif yang berbentuk studi kasus dengan teknik pengumpulan data melalui wawancara, observasi, pemeriksaan fisik, studi dokumentasi, studi kepustakaan. menanyakan langsung kepada klien, keluarga, perawat, dan dokter yang menangani dan mengetahui masalah atau keluhan klien.

Hasil: Sesuai hasil temuan di atas terdapat 4 masalah keperawatan yang muncul diantaranya Nyeri akut, Hambatan mobilitas fisik, resiko infeksi dan defisit perawatan diri. Tindakan keperawatan yang utama yang di berikan adalah management nyeri, latihan mobilitas fisik, monitoring tanda tanda vital dan perawatanluka post operasi.

Kesimpulan: Kesimpulan dari asuhan keperawatan bahwa pencapaian hasil optimal dapat dicapai apabila kita melaksanakan proses keperawatan secara komprehensif yang meliputi aspek bio-psiko-sosio dan spiritual serta ditunjang dari kerjasama dengan klien, keluarga dan tenaga kesehatan yang lain.

Kata kunci: asuhan keperawatan; gangguan sistem muskuloskeletal post op orif; fraktur femur sisnistra. 


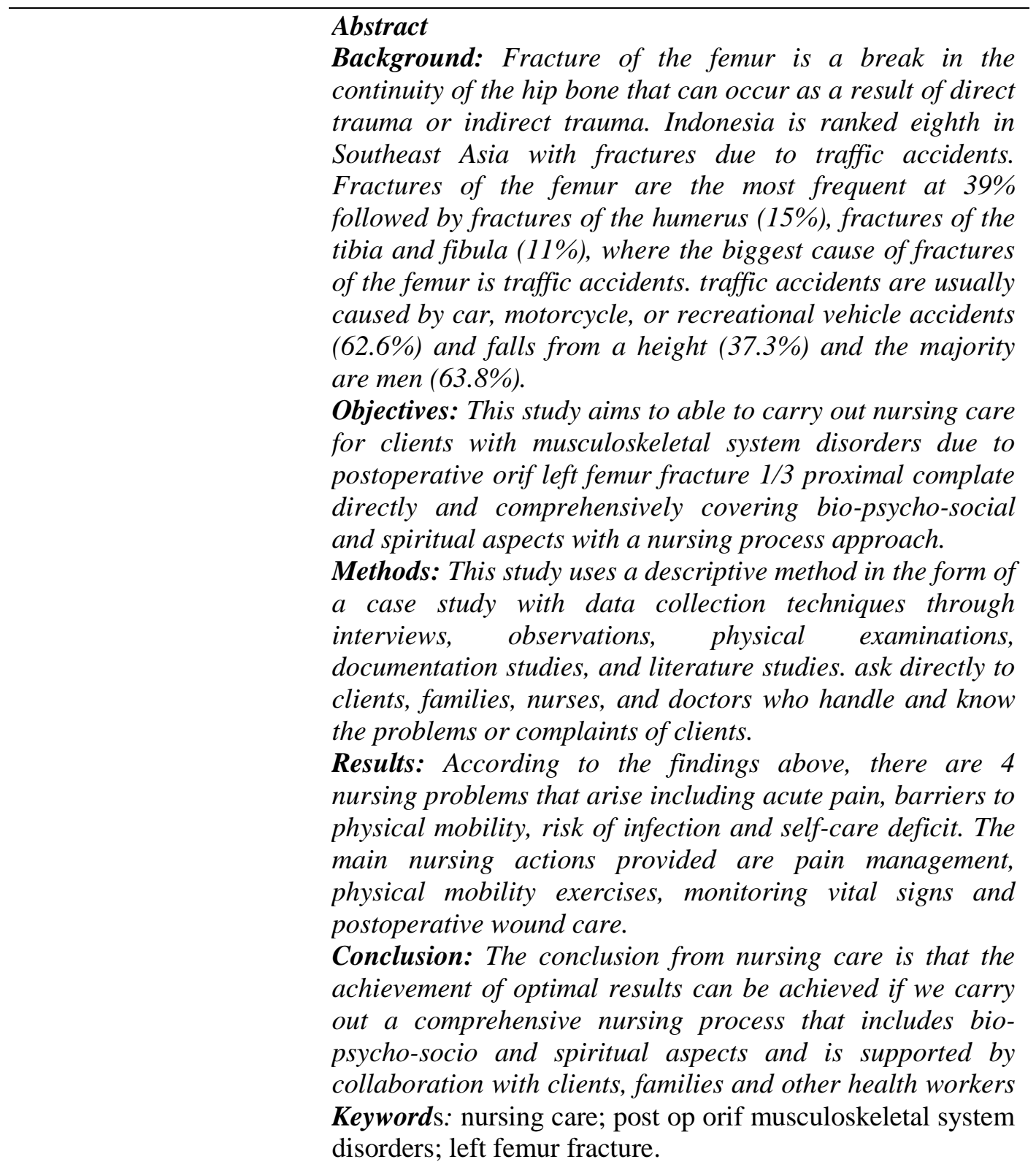

*Correspondent Author : R. Deni Indrawan Email : deniindrawancrb@gmail.com

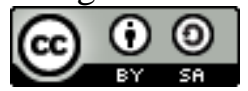

\section{PENDAHULUAN}

Menurut (Adliyani, 2015) kesehataan adalah keadaan sakit, baik secara fisik, mental, spritual maupun sosial yang memungkinkan setiap orang untuk hidup produktif secara sosial maupun ekomomi. Menurut (Organization, 2015) sehat adalah kondisi dinamis meliputi kesehatan jasmani, rohani, sosial, dan tidak hanya terbebas dari penyakit, cacat, dan kelemahan. Sehat secara mental/psikis adalah sehatnya pikiran, emosional, maupun spiritual dari seseorang. 
Menurut (Fikri \& Maesaroh, 2020) sakit adalah keadaan kesehatan yang buruk ditandai dengan penyimpangan status kesehatan normal. Menurut (Desmeules et al., 2012) sakit adalah suatu keadaan tidak menyenangkan yang menimpa seseorang sehingga menimbulkan gangguan pada aktivitas sehari-hari, baik aktivitas jasmani maupun sosial.

World Health Organization (WHO) mencatat di tahun 2011 terdapat lebih dari 5,6 juta orang meninggal dikarenakan insiden kecelakaan dan sekitar 1,3 juta orang mengalami kecacatan fisik (Organization, 2011). Kecelakaan memiliki prevalensi cukup tinggi yaitu insiden fraktur ekstremitas bawah sekitar 40\% (Depkes, 2011). Fraktur di Indonesia menjadi penyebab kematian terbesar ketiga di bawah penyakit jantung koroner dan tuberculosis (Wulandini et al., 2018).

Menurut (Ariyanti, 2013) Fraktur adalah kondisi ketika tulang patah sehingga posisi atau bentukmya berubah. Patah tulang dapat terjadi jika tulang menerima tekanan atau benturan yang kekuatannya lebih besar daripada kekuataan tulang. Riset Kesehatan Dasar (2011) Menemukan ada sebanyak 45.987, peristiwa terjatuh yang mengalami fraktur sebanyak 1.775 orang $(3,8 \%)$. Kasus kecelakaan lalu lintas sebanyak 20.829 kasus, dan yang mengalami fraktur sebanyak 1.770 orang $(8,5 \%)$, dari 14.127 trauma benda tajam/tumpul, yang mengalami fraktur sebanyak 236 orang $(1,7 \%)$.

Menurut (Wulandini et al., 2018) dalam jurnalnya, Fraktur femur adalah diskontinuitas dari femoral shaft yang bisa terjadi akibat trauma secara langsung (kecelakaan lalu lintas atau jatuh dari ketinggian), dan biasanya lebih banyak dialami laki laki dewasa. Apabila seseorang mengalami fraktur pada bagian ini, pasien akan mengalami perdarahan yang banyak dan dapat mengakibatkan penderita mengalami syok. Fraktur femur dapat menyebabkan komplikasi, morbiditas yang lama dan juga kecacatan apabila tidak mendapatkan penanganan yang baik. Insiden fraktur femur pada wanita adalah fraktur terbanyak kedua (17,0 per 10.000 orang per tahun) dan nomer tujuh pada pria (5,3 per orang per tahun). Puncak distribusi usia pada fraktur femur adalah pada usia dewasa (15 - 34 tahun) dan orang tua (diatas 70 tahun).

Salah satu manifestasi klinis dari fraktur adalah nyeri. Nyeri merupakan perasaan yang tidak menyenangkan yang sering kali dialami oleh individu yang didefinisikan dalam berbagai perspektif. Mengantisipasi nyeri pada pasien fraktur dapat dilakukan secara farmakologis yaitu dengan menggunakan obat-obatan dan nonfarmakologis. Salah satu pengobatan nonfarmakologis yaitu dengan teknik distraksi. Distraksi adalah memfokuskan perhatian klien pada sesuatu selain nyeri, atau dapat diartikan lain bahwa distraksi adalah suatu tindakan pengalihan perhatian klien ke hal-hal diluar nyeri. Dengan demikian diharapkan, klien tidak terfokus pada nyeri lagi dan dapat menurunkan kewaspadaan klien terhadap nyeri bahkan meningkatkan toleransi terhadap nyeri. Mendengarkan musik merupakan salah satu teknik distraksi yang efektif. Musik dapat menurunkan nyeri fisiologis, stress dan kecemasan dengan mengalihkan perhatian seseorang dari nyeri.

Menurut (Depkes, 2014) kasus fraktur femur merupakan yang paling sering yaitu sebesar 39\% diikuti fraktur humerus (15\%), fraktur tibia dan fibula (11\%), dimana penyebab terbesar fraktur femur adalah kecelakaan lalu lintas yang biasanya disebabkan oleh kecelekaan mobil, motor, atau kendaraan rekreasi $(62,6 \%)$ dan jatuh dari ketinggian $(37,3 \%)$ dan mayoritas adalah pria $(63,8 \%)$.

Menurut (Tengah, 2013) Angka kematian kecelakaan lalu lintas adalah jumlah kematian sebagai akibat kecelakaan lalu lintas per 100.000 penduduk dalam kurun waktu satu tahun. Di provinsi Jawa Tengah didapatkan sekitar 2.700 orang mengalami fraktur, $56 \%$ mengalami kecacatan fisik, $24 \%$ mengalami kematian, $15 \%$ mengalami ksembuhan dan $5 \%$ mengalami gangguan psikologis atau depresi terhadap adanya kejadian fraktur.

Berdasarkan uraian latar belakang diatas maka penulis tertarik untuk menindak lanjuti Asuhan Keperawatan pada klien dengan gangguan sistem muskuloskletal akibat post orif femur yang penulis tuangkan dalam bentuk Karya Tulis Ilmiah dengan judul: "Asuhan Keperawatan Pada Ny.S Dengan Gangguan Sistem Muskuloskeletal Akibat 
Post Operasi Orif Hari Ke-1 Fraktur Femur Sinistra 1/3 Proximal Complate Diruang Lavender Bawah Wanita RSUD Kardinah Tegal”.

\section{METODE PENELITIAN}

Penelitian ini menggunakan metode deskriptif yang berbentuk studi kasus dengan teknik pengumpulan data dengan melalui wawancara, observasi, pemeriksaan fisik, studi dokumentasi, studi kepustakaan. menanyakan langsung kepada klien, keluarga, perawat, dan dokter yang menangani dan mengetahui masalah atau keluhan klien.

\section{HASIL DAN PEMBAHASAN}

\section{A. Hasil Penelitian}

\section{Pengkajian}

Tabel 1. Diagnosa Keperawatan

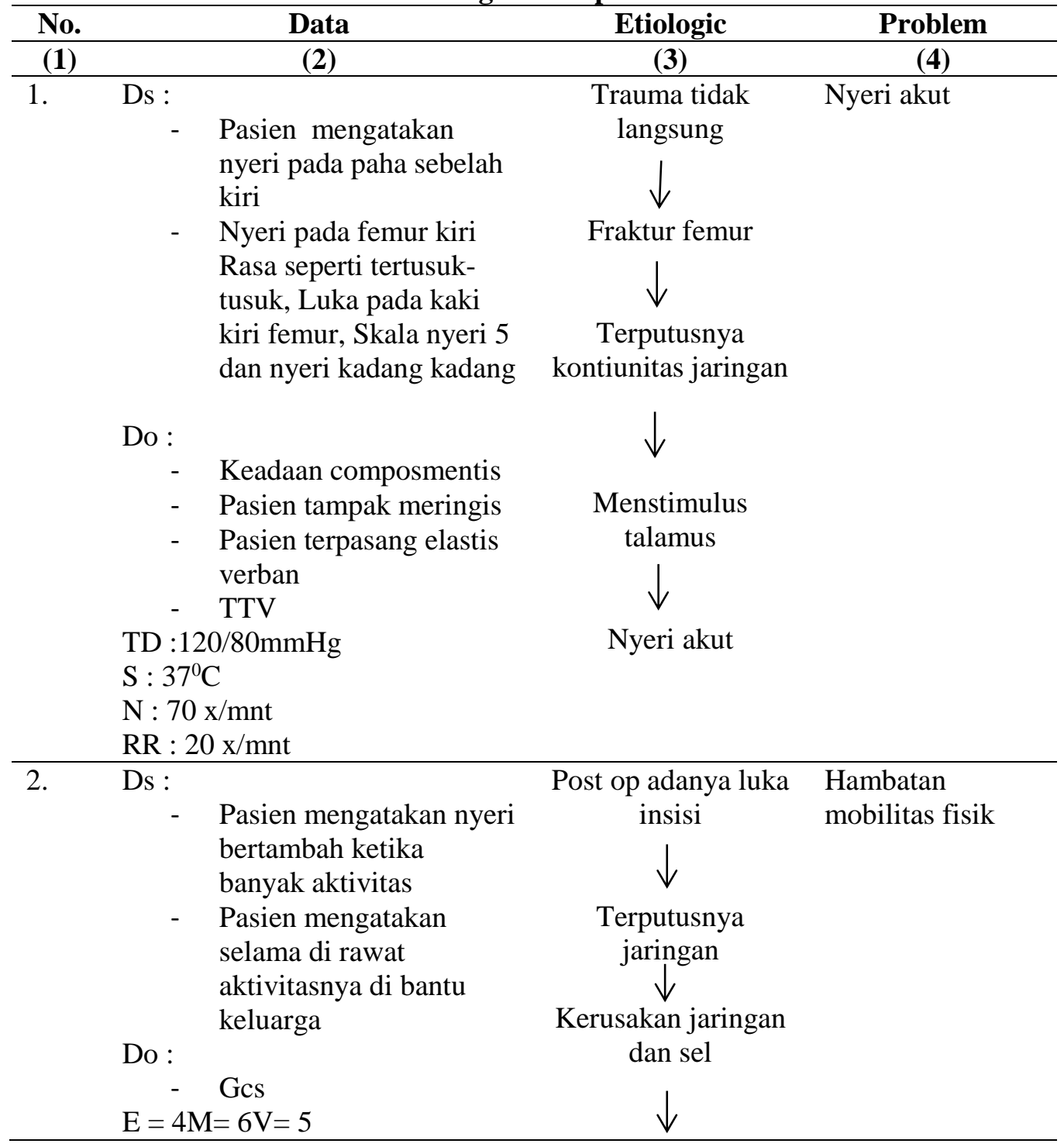




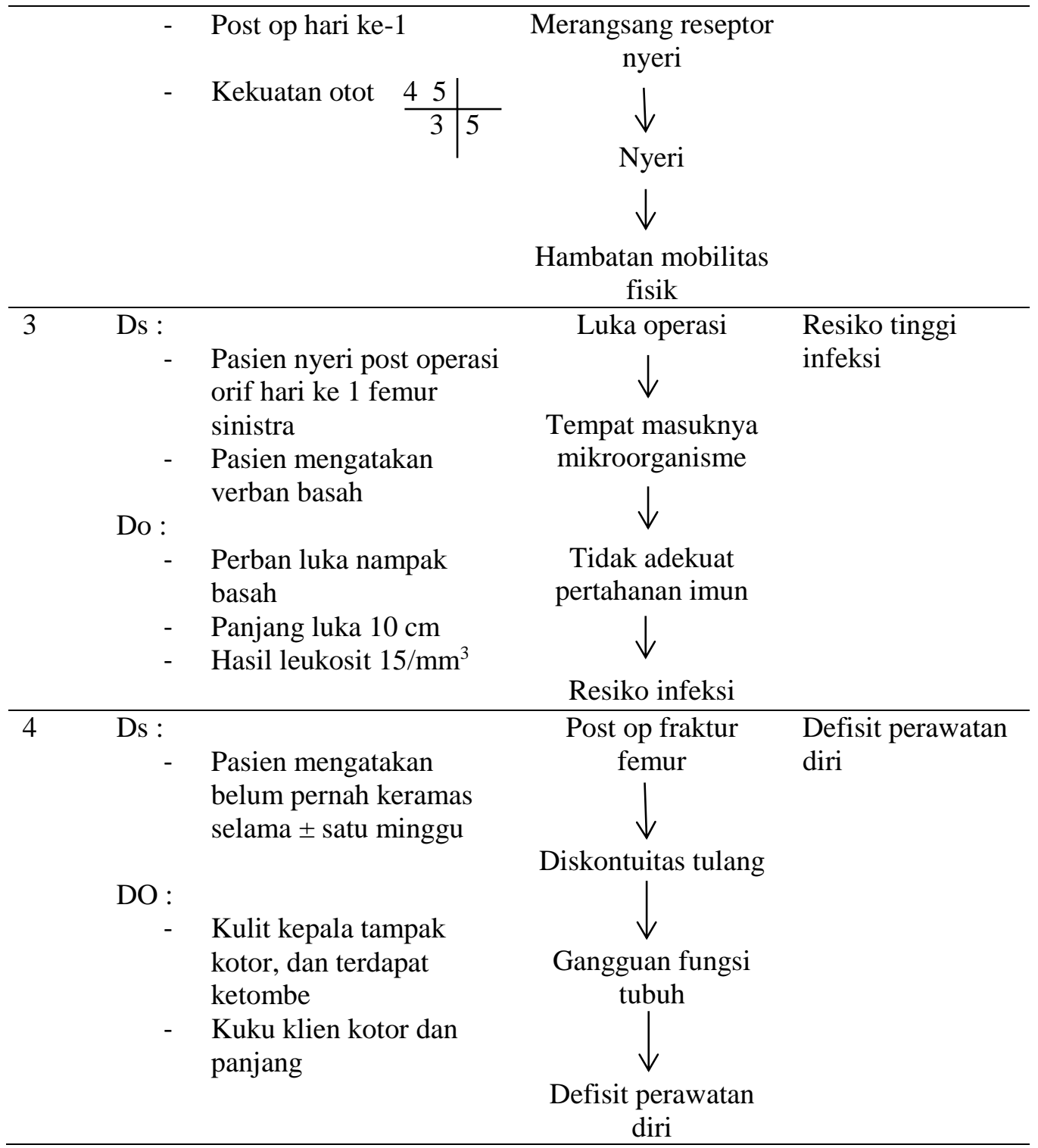

\section{Diagnosa keperawatan}

a. Nyeri akut berhubungan dengan trauma jaringan, post operasi fraktur femur ditandai dengan pasien mengatakan nyeri pada paha kiri, nyeri seperti di tusuk tusuk, bertambah nyeri saat klien banyak aktivitas dan berkurang saat istirahat, nyeri kadang kadang, Skala nyeri 5(1-10).TD :120/80mmHg. N : 70 x/mntRR : 20 $\mathrm{x} / \mathrm{mnt} \mathrm{S}: 36^{\circ} \mathrm{C}$.

b. Hambatan mobilitas fisik berhubungan dengan kerusakan angka neuromuscular nyeri ditandai dengan pasien mengatakan nyeri bertambah ketika banyak aktivitas, aktivitas klien di bantu oleh keluarga.

c. Resiko tinggi infeksi berhubungan dengan prosedur invasif ditandai dengan pasien post operasi orif dan perban nampak basah, panjang luka post op $10 \mathrm{~cm}$, Hasil leukosit $15 / \mathrm{mm}^{3}$.

d. Defisit perawatan diri berhubungan dengan ganggun fungsi ditandai dengan pasien mengatakan belum pernah keramas, rambut nampak kotor terdapat ketombe. 


\section{Intervensi keperawatan}

Tabel 2. Intervensi keperawatan

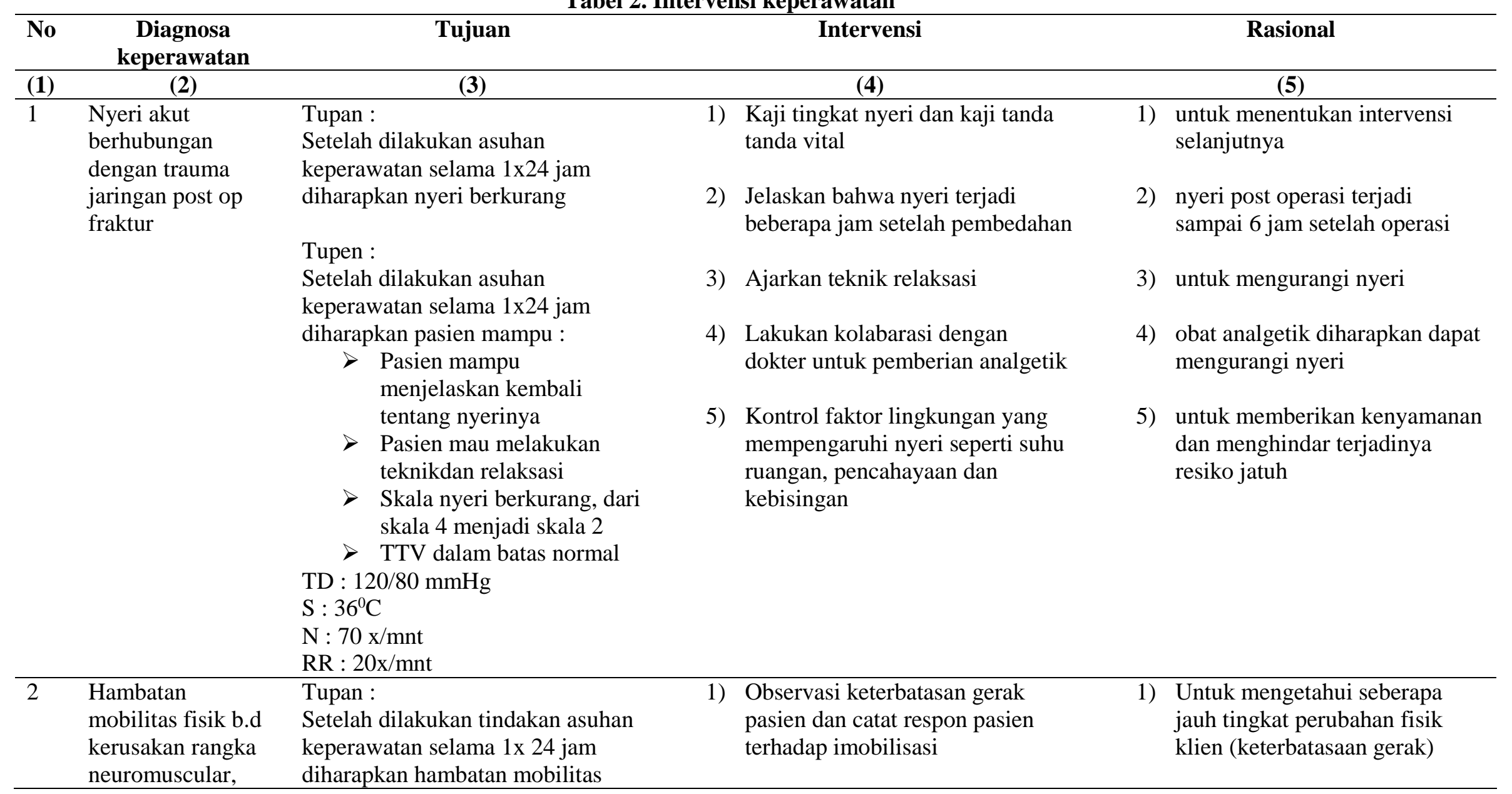

Asuhan Keperawatan Pada Ny.S dengan Gangguan Sistem Muskuloskeletal Post Op Orif Hari Ke-1 Akibat Fraktur Femur Sinistra 1/3 Proximal 


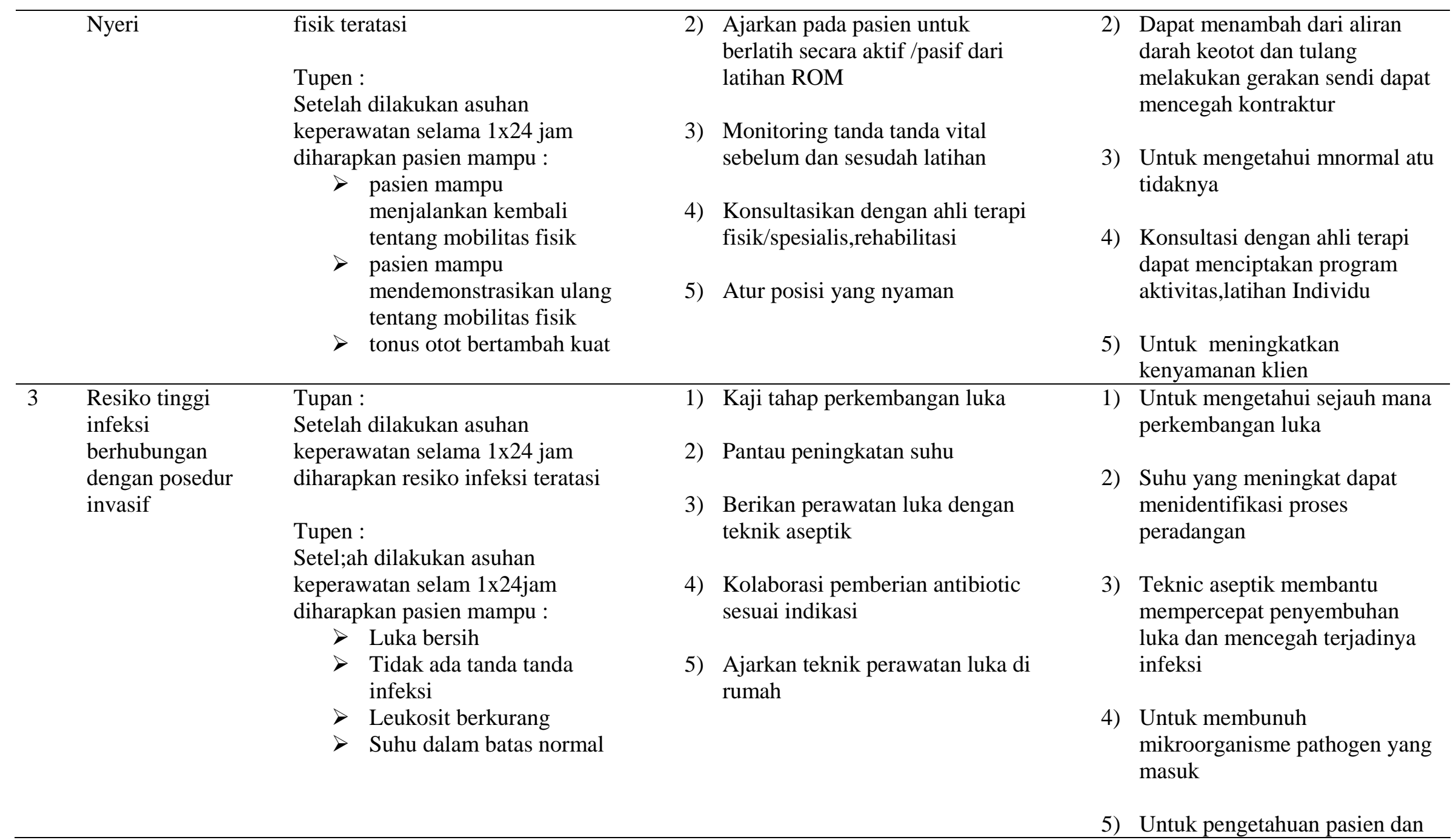




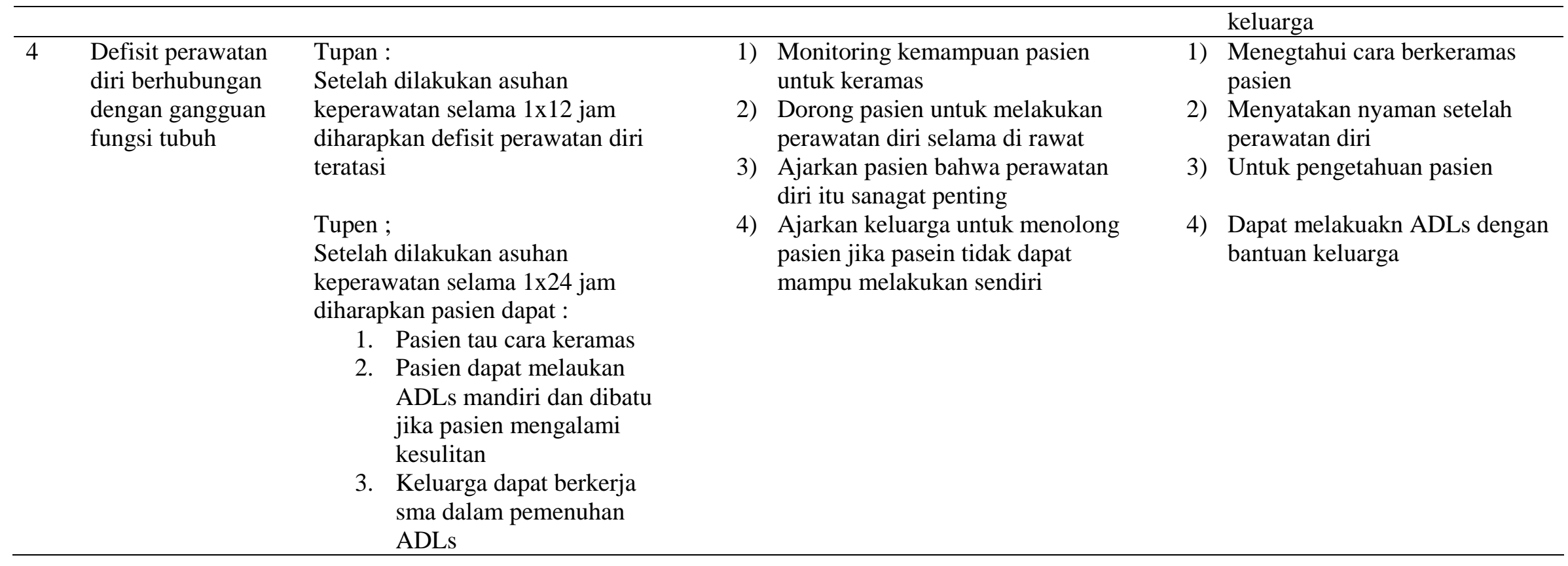




\section{Implementasi}

Tabel 3. Implementasi Keperawatan

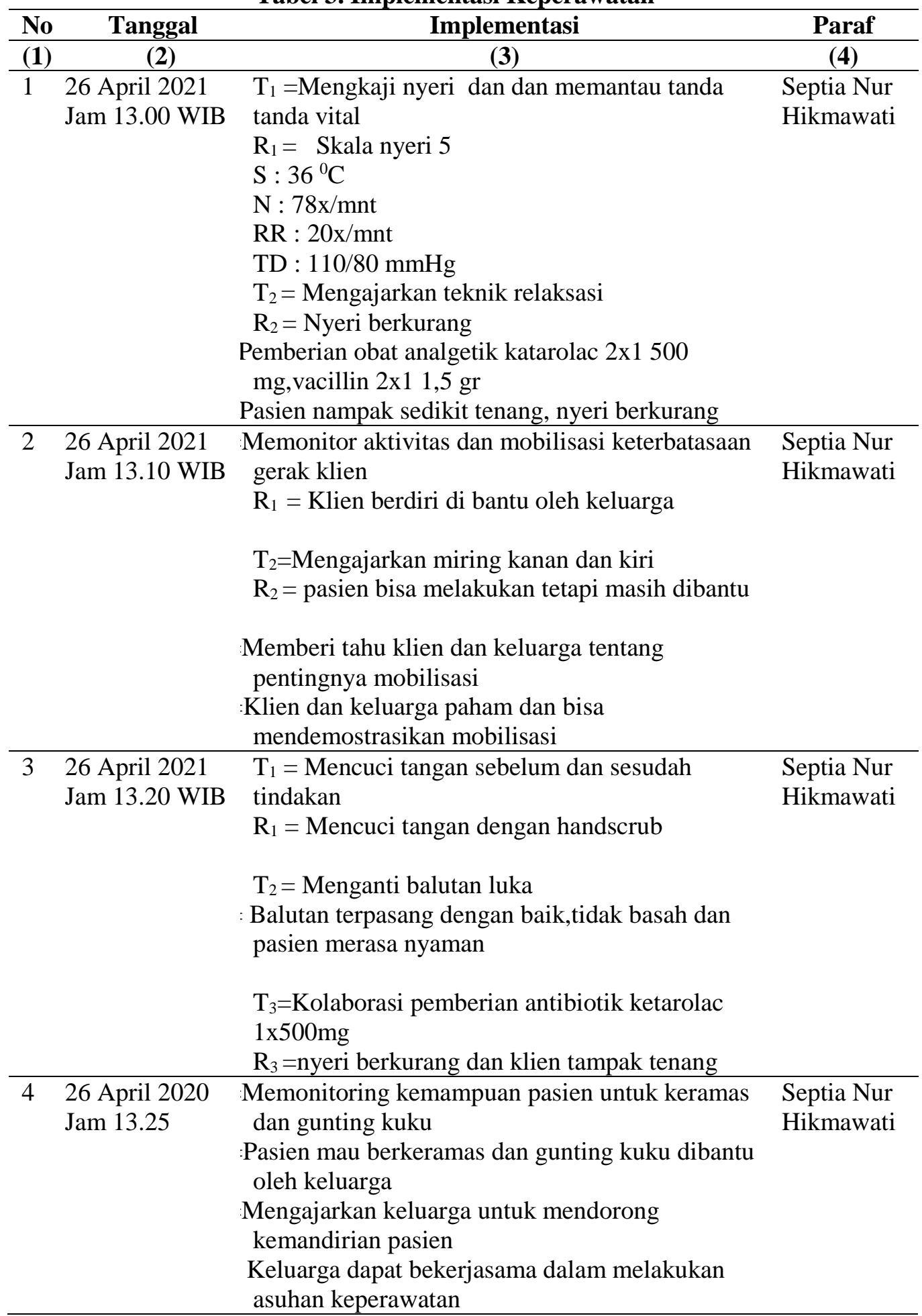




\section{Evaluasi}

Tabel 4. Evaluasi keperawatan

\begin{tabular}{|c|c|c|c|c|}
\hline No & Tanggal & Dx & Evaluasi & Paraf \\
\hline (1) & (2) & (3) & (4) & (5) \\
\hline 1 & $\begin{array}{l}26 \text { April } \\
2021 \\
\text { Jam } 14.00 \\
\text { WIB }\end{array}$ & $\begin{array}{l}\text { Nyeri akut b.d } \\
\text { trauma jaringan } \\
\text { post operasi } \\
\text { fracture }\end{array}$ & 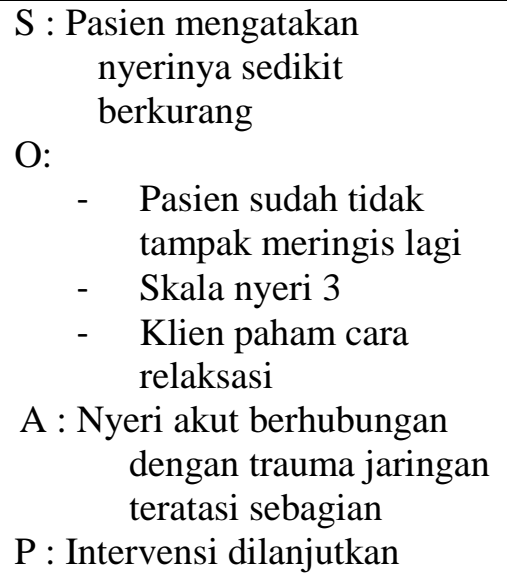 & $\begin{array}{l}\text { Septia Nur } \\
\text { Hikmawati }\end{array}$ \\
\hline 2 & $\begin{array}{l}26 \text { April } \\
2021 \\
\text { Jam } 14.10\end{array}$ & $\begin{array}{l}\text { Hambatan } \\
\text { mobilitas fisik b.d } \\
\text { kerusakan rangka } \\
\text { neuromuscular, }\end{array}$ & $\begin{array}{cl}\mathrm{S}: & \text { Pasien mengatakan sudah } \\
& \text { mulai bisa beraktivitas } \\
& \text { sedikit sedikit } \\
\mathrm{O}: & \\
& \text { Pasien sudah bisa } \\
& \text { duduk sendiri } \\
& \text { Aktivitas nampak } \\
& \text { masih di bantu } \\
& \text { keluarga } \\
\text { A : Hambatan mobilitas fisik } & \text { berhubungan dengan } \\
\text { fraktur teratasi sebagian } & \\
\text { P : Intervensi di lanjutkan }\end{array}$ & $\begin{array}{l}\text { Septia Nur } \\
\text { Hikmawati }\end{array}$ \\
\hline 3 & $\begin{array}{l}26 \text { April } \\
2021 \\
\text { Jam } 14.20 \\
\text { WIB }\end{array}$ & $\begin{array}{l}\text { Resiko infeksi b.d } \\
\text { luka post operasi }\end{array}$ & $\begin{array}{l}\mathrm{S}: \text { Pasien mengatakan nyeri } \\
\text { post op berkurang } \\
\mathrm{O}: \\
\quad-\quad \text { Panjang luka } 3 \mathrm{~cm} \\
-\quad \text { Leukosit } 15 \mathrm{~mm} / \mathrm{hg} \\
\mathrm{A}: \text { Resiko infeksi } \\
\quad \begin{array}{l}\text { berhubungan dengan post } \\
\text { op orif teratasi sebagian }\end{array} \\
\mathrm{P}: \text { Intervensi dilanjutkan }\end{array}$ & $\begin{array}{l}\text { Septia Nur } \\
\text { Hikmawati }\end{array}$ \\
\hline 4 & $\begin{array}{l}26 \text { April } \\
2021 \\
\text { Jam } 14.30\end{array}$ & $\begin{array}{l}\text { Defisit perawatan } \\
\text { diri berhubungan } \\
\text { dengan gangguan } \\
\text { fungsi tubuh }\end{array}$ & 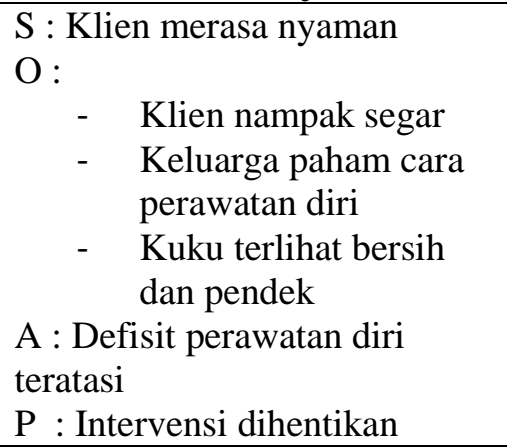 & $\begin{array}{l}\text { Septia Nur } \\
\text { Hikmawati }\end{array}$ \\
\hline
\end{tabular}




\section{Catatan perkembangan}

Tabel 5. Catatan Perkembangan

\begin{tabular}{|c|c|c|c|c|}
\hline No & Tanggal & Dx & Evaluasi & Paraf \\
\hline (1) & (2) & (3) & (4) & (5) \\
\hline 1 & $\begin{array}{l}27 \text { April } \\
2021 \\
\text { Jam } 09.00 \\
\text { WIB }\end{array}$ & $\begin{array}{l}\text { Nyeri akut b.d } \\
\text { trauma jaringan } \\
\text { post operasi } \\
\text { fracture }\end{array}$ & 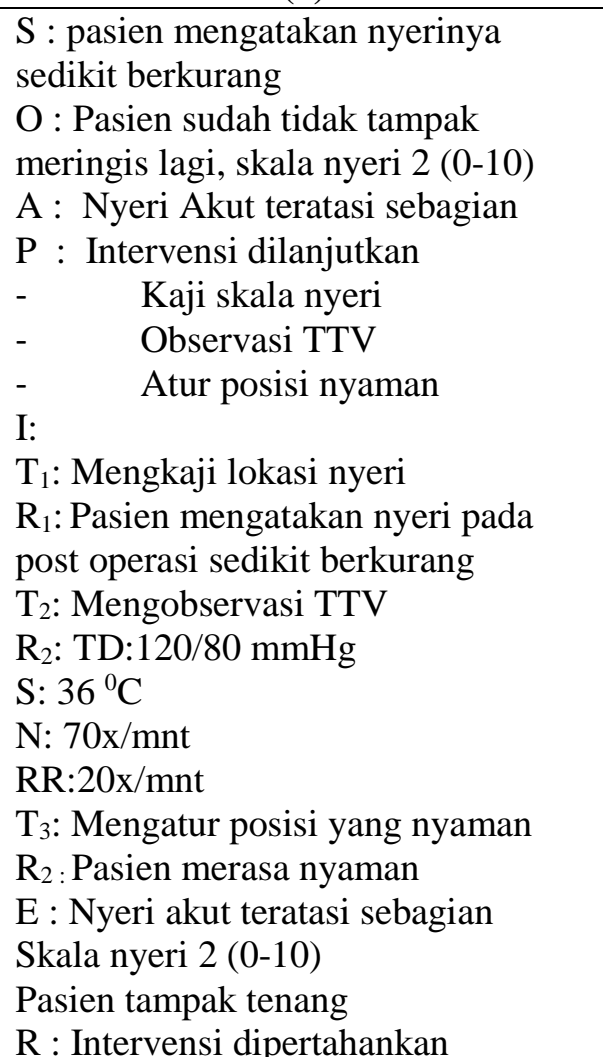 & $\begin{array}{l}\text { Septia Nur } \\
\text { Hikmawati }\end{array}$ \\
\hline 2 & $\begin{array}{l}27 \text { April } \\
2021 \\
\text { Jam } 09.10 \\
\text { WIB }\end{array}$ & $\begin{array}{l}\text { Hambatan } \\
\text { mobilitas fisik } \\
\text { b.d kerusakan } \\
\text { rangka } \\
\text { neuromuscular, } \\
\text { nyeri terapi } \\
\text { restraksi }\end{array}$ & $\begin{array}{l}\mathrm{S} \text { : Pasien mengatakan sudah mulai } \\
\text { bisa beraktivitas } \\
\mathrm{O}: \\
\text { - Pasien sudah bisa duduk sendiri } \\
\text { - Aktivitas sedikit dibantu keluarga } \\
\text { - Pasien bisa makan dan minum } \\
\text { sendiri } \\
\mathrm{A} \text { : Hambatan mobilitas fisik teratasi } \\
\text { sebagian } \\
\mathrm{P}: \text { Intervensi di lanjutkan } \\
\text { 1. Kaji kemampuan mobilitas } \\
\quad \text { pasien } \\
\text { 2. Ajarkan pasien untuk berlatih } \\
\quad \text { ROM secara aktif dan pasif } \\
\text { I : } \\
\mathrm{T}_{1} \text { : Kaji kemampuan mobilitas } \\
\text { pasien } \\
\mathrm{R} 1: \text { Pasien meningkat dalam aktivitas, } \\
\text { seperti bisa duduk } \\
\mathrm{T}_{2} \text { : Mengajarkan pada pasien untuk } \\
\text { berlatih secara aktif/pasif dari latihan } \\
\text { ROM }\end{array}$ & $\begin{array}{l}\text { Septia Nur } \\
\text { Hikmawati }\end{array}$ \\
\hline
\end{tabular}




\begin{tabular}{|c|c|c|c|c|}
\hline & & & $\begin{array}{l}\mathrm{R}_{2}: \text { Pasien mampu melakukan } \\
\text { latihan ROM } \\
\mathrm{E}: \text { Pasien meningkat dalam aktivitas } \\
\text { tetapi sebagian dibantu, Masalah } \\
\text { teratasi sebagian } \\
\mathrm{R}: \text { Intervensi dipertahankan }\end{array}$ & \\
\hline 3 & $\begin{array}{l}27 \text { April } \\
2021 \\
\text { Jam } 09.20 \\
\text { WIB }\end{array}$ & $\begin{array}{l}\text { Resiko infeksi } \\
\text { berhubungan } \\
\text { dengan luka op }\end{array}$ & $\begin{array}{l}\mathrm{S}: \text { Pasien mengatakan nyeri sudah } \\
\text { berkurang dan mengerti cara } \\
\text { merawat luka } \\
\mathrm{O}: \\
-\quad \quad \text { Luka post op masih basah } \\
-\quad \text { Leuklosit } 13 \mathrm{~mm}^{3} \\
\text { A : Resiko infeksi teratasi } \\
\text { sebagian } \\
\mathrm{P}: \text { Intervensi di lanjutkan }\end{array}$ & $\begin{array}{l}\text { Septia Nur } \\
\text { Hikmawati }\end{array}$ \\
\hline
\end{tabular}

\section{B. Pembahasan}

Telah diberikan asuhan keperawatan pada Ny. S dengan gangguan sistem muskuloskleletal akibat post op orif hari ke 1 fraktur femer sinistra 1/3 proximal complate dari tanggal 25-26 April 2021 di ruang lavender bawah wanita RSUD Kardinah Tegal. Perawat melakukan metode keperawatan mulai dari pengkajian, diagnosa keperawatan, perencanaan, pelaksanaan, dan evaluasi. Penulis menemukan beberapa kesenjangan dan kesamaan yang penulis temukan, diantaranya :

1. Pengkajian

Pada tahap ini, penulis mengumpulkan data dengan bertatap muka langsung dengan pasien dan keluarga mengunakan teknik wawancara, observasi, studi dokumentasi, dan studi literature yaitu melibatkan pasien dan keluarga dan mengidentifikasi data yang diperlukan selama pengkajian dan penulis juga menyamakan data dengan dokumentasi catatan medis pasien yang berada di ruangan perawat, penulis melakukan pemeriksaan fisik dan pemeriksan lainnya seperti pemeriksaan laboratorium dan rotgen.

Penulis menemukan data pada Ny. S dengan post orif fraktur femur sinistra yaitu pasien mengeluh nyeri di paha kiri, aktivitas dibantu keluarga, terdapat luka post op orif hari ke-1, dan kebersihan rambut dan kuku pasien kurang terjaga. Sedangkan dalam teori pasien post op orif adalah sebagai berikut : Nyeri hebat, bengkak, deformitas, mati rasa dan masalah pergerakan pada anggota tubuh dan terjadi defisit perawatan diri karena gangguan fungsi tubuh dan pada kasus fraktur kemungkinan mengalami resiko tinggi infeksi. Dari data di atas, terdapat kesenjangan maupun kesamaan antara kasus dan teori sehingga penulis tuangkan dalam hal berikut :

a. Hasil pengkajian yang sama antara teori dan praktik : pasien mengeluh nyeri, aktivitas terbatas, dan defisit perawatan diri.

b. Hasil pengkajian yang tidak sama dengan teori adalah pasien tidak mengalami mati rasa.

Penulis dapat simpulkan, bahwa kesenjangan maupun kesamaan antara teori dan kasus merupakan bukti setiap individu memiliki mekanisme konpensasi yang berbeda.

2. Diagnosa keperawatan 
Setelah pengkajian, penulis melakukan analisa data untuk menentukan diagnosa keperawatan pada pasien Ny. S dengan gangguan sistem muskuloskeletal akibat post op hari ke 1 fraktur femur sinistra 1/3 Proximal complate dengan diagnosa :

a. Diagnosa keperawatan yang muncul menurut teori

1) Nyeri akut berhubungan dengan agen cidera fisik.

2) Hambatan mobilitas fisik berhubungan dengan kerusakan angka neuromuscular nyeri.

3) Resiko infeksi berhubungan dengan tindakan pembedahan

4) Defisit perawatan diri berhubungan dengan gangguan fungsi tubuh

5) Kerusakan integritas jaringan berhubungan dengan faktor mekanik

6) Ketidakefektifan perfusi jaringan perifer berhubungan dengan penurunan suplai darah ke jaringan.

b. Adapun diagnosa keperawatan yang muncul sesuai kasus, sebagi berikut :

1) Nyeri akut berhubungan dengan trauma jaringan, post operasi fraktur femur ditandai dengan pasien mengatakan nyeri pada paha kiri, nyeri seperti di tusuk tusuk, bertambah nyeri saat klien banyak aktivitas dan berkurang saat istirahat, nyeri kadang kadang, Skala nyeri 5(1-10).TD :120/80mmHg. $\mathrm{N}: 70 \mathrm{x} / \mathrm{mntRR}: 20 \mathrm{x} / \mathrm{mnt} \mathrm{S}: 36^{\circ} \mathrm{C}$.

2) Hambatan mobilitas fisik berhubungan dengan kerusakan angka neuromuscular nyeri ditandai dengan pasien mengatakan nyeri bertambah ketika banyak aktivitas, aktivitas klien di bantu oleh keluarga dan tonus otot 3 .

3) Resiko tinggi infeksi berhubungan dengan prosedur invasif ditandai dengan pasien post operasi orif dan perban nampak basah, panjang luka post op $10 \mathrm{~cm}$, Hasil leukosit $15 / \mathrm{mm}^{3}$.

4) Defisit perawatan diri berhubungan dengan ganggun fungsi ditandai dengan pasien mengatakan belum pernah keramas, rambut nampak kotor terdapat ketombe dan kuku klien nampak kotor dan panjang.

Berdasarkan data tersebut dapat dilihat antara tinjauan kasus dan tinjauan teoritis terdapat kesenjangan yaitu,pada teori terdapat ketidakefektifan perfusi jaringan perifer ditandai dengan suplai darah kurang ke jaringan. Namun setelah di analisis klien tidak ada tanda tanda yang merujuk ke diagnosa tersebut contoh turgor kulit normal, nadi normal dan proses penyembuhan luka tergolong cepat. klien hanya beberapa saja hal ini terjadi karena tidak ada tanda dan gejala yang menunjang dan setiap individu memiliki respon berbeda terhadap penyakit sehingga menyebabkan respon yang dialami klien berbeda.

3. Perencanaan

Tahap perencanaan penulis tidak menemukan hambatan, karena rencana tindakan sesuaikan dengan masalah yang muncul dengan mempertimbangkan kondisi klien sebagai pribadi yang dinamis dilihat dari aspek bio, psiko, sosial dan spiritual. Adapun rencana yang dicantumkan yaitu guna mengatasi masalah yang ditemukan pada klien. Penyusun rencana tindakan keperawatan hendaknya melibati klien, dan keluarga serta tenaga medis lainnya.

4. Implementasi

Tahap implementasi tidak terdapat kesenjangan, namun terdapat kendala hal ini dikarenakan penulis tidak selalu berada bersama klien. Namun klien bekerja sama dengan baik, baik dengan penulis, keluarga dan perawat sehingga pelaksanaan asuhan keperawatan dapat dilakukan dengan baik.

5. Evaluasi

Asuhan Keperawatan Pada Ny.S dengan Gangguan Sistem Muskuloskeletal Post Op Orif Hari Ke-1 Akibat Fraktur Femur Sinistra 1/3 Proximal Complate 
Evaluasi merupakan bagian dari proses keperawatan. Penulis mengevaluasi dari intervensi yang telah dilakukan. Tujuannya diharapkan sesuai dengan kriteria waktu sehingga dapat mempermudah dalam intervensi selanjutnya. Dalam tahap evaluasi klien menunjukan respon yang baik adapun permasalah klien.Penulis tidak mengalami hambatan karena sudah ada kriteria hasil dari keberhasilan yang tertuang pada tujuan asuhan keperawatan sebagai berikut :

a. Diagnosa keperawatan yang teratasi sebagian

1) Nyeri akut berhubungan dengan fraktur femur. Masalah teratasi sebagian, skala nyeri berkurang menjadi 2 dan masih diberikan obat analgetik yaitu caterolac

2) Hambatan mobilitas fisik berhubungan dengan fraktur. Masalah teratasi sebagian karena aktivitas klien nampak dibantu oleh keluarga tapi ada peningkatan aktivitas klien dari hari ke hari

b. Diagnosa keperawatan yang teratasi

1) Defisit perawatan diri berhubungan dengan gangguan fungsi tubuh masalah ini teratasi karena keluarga klien dapat bekerja sama dalam memenuhi kebutuhan perawatan diri klien. Pasien ditemani oleh ibunya yang sangat perhatian.

2) Resiko infeksi berhubungan dengan luka post op. Masalah ini harus selalu di monotoring selama beberapa hari karena luka post operasi dan untuk menghindari terjadinya tanda tanda infeksi

6. Catatan perkembangan

Merupakan semua catatan yang berhubungan dengan keadaan pasien selama dalam perawatan. Catatan ini menyediakan suatu rekaman kemajuan pasien dalam mengatasi masalah khusus, perencanaan dan evaluasi. Dalam tahap catatan perkembangan, penulis tidak menemukan hambatan yang berarti. Keluarga pasien menunjukan respon yang baik adapun permasalahan klien terayasi, namun jika masalah muncul kembali penulis sudah menganjurkan ke keluarga untuk melakukan tindakan keperawatan secara mandiri ataupun merujuk ke pelayanan kesehatan lain.

\section{KESIMPULAN}

Asuhan keperawatan yang penulis berikan pada Ny. S dengan gangguan sistem muskuloskletal akibat post orif hari ke-1 fraktur femur sinistra 1/3 proximal complate diruang lavender bawah wanita RSUD Kardinah Tegal yang dilaksanakan pada tanggal 25-26 April 2021 dilaksanakan dengan hati yang tulus dan ikhlash. Penulis melakukan asuhan keperawatan yang bertujuan untuk mendokumentasikan ke dalam bentuk karya tulis ilmiah,maka penulis dapat mengambil kesimpulan sebagai berikut World Health Organization (WHO) mencatat di tahun 2011 terdapat lebih dari 5,6 juta orang meninggal dikarenakan insiden kecelakaan dan sekitar 1,3 juta orang mengalami kecacatan fisik (Organization, 2011). Kecelakaan memiliki prevalensi cukup tinggi yaitu insiden fraktur ekstremitas bawah sekitar $40 \%$.fraktur di Indonesia menjadi penyebab kematian terbesar ketiga di bawah penyakit jantung koroner dan tuberculosis.

Fraktur femur adalah diskontinuitas dari femoral shaft yang bisa terjadi akibat trauma secara langsung (kecelakaan lalu lintas atau jatuh dari ketinggian), dan biasanya lebih banyak dialami laki laki dewasa. Apabila seseorang mengalami fraktur pada bagian ini, pasien akan mengalami perdarahan yang banyak dan dapat mengakibatkan penderita mengalami syok.

Setelah dilakukan asuhan keperawatan pada Ny. S dengan gangguan sistem muskuloskeletal akibat post orif hari ke-1 fraktur femur sinistra $1 / 3$ proximal complate 
ditemukan 4 diagnosa yaitu nyeri akut berhubungan dengan trauma jaringan, post operasi fraktur femur ditandai dengan pasien mengatakan nyeri pada paha kiri, nyeri seperti di tusuk tusuk, bertambah nyeri saat klien banyak aktivitas, nyeri kadang kadang, Skala nyeri 5(1-10).TD :120/80mmHgN : $70 \mathrm{x} / \mathrm{mntRR}$ : $20 \mathrm{x} / \mathrm{mnt} \mathrm{S}: 36{ }^{0} \mathrm{C}$. Hambatan mobilitas fisik berhubungan dengan kerusakan angka neuromuscular nyeri ditandai dengan pasien mengatakan nyeri bertambah ketika banyak aktivitas, aktivitas klien di bantu oleh keluarga dan tonus otot 3 . Resiko tinggi infeksi berhubungan dengan prosedur invasif ditandai dengan pasien post operasi orif dan perban nampak basah, panjang luka post op $3 \mathrm{~cm}$, Hasil leukosit 15/ $\mathrm{mm}^{3}$. Defisit perawatan diri berhubungan dengan ganggun fungsi ditandai dengan pasien mengatakan belum pernah keramas dan rambut nampak kotor terdapat ketombe dan kuku nampak kotor dan panjang

\section{BIBLIOGRAFI}

Adliyani, Z. O. N. (2015). Pengaruh perilaku individu terhadap hidup sehat. Jurnal Majority, 4(7), 109-114.

Ariyanti, D. (2013). Efektivitas Active Asistive Range of Motion Terhadap Kekuatan Otot Ekstremitas Pada Pasien Stroke Non Hemoragik. Karya Ilmiah.

Depkes, R. I. (2011). Badan penelitian dan pengembangan Kesehatan. Riset Kesehatan Dasar.

Depkes, R. I. (2014). Peraturan Menteri Kesehatan Republik Indonesia Nomor 56 Tahun 2014 tentang Klasifikasi dan Perijinan Rumah Sakit. Jakarta: Departemen Kesehatan RI.

Desmeules, J., Piguet, V., Besson, M., Chabert, J., Rapiti, E., Rebsamen, M., Rossier, M. F., Curtin, F., Dayer, P., \& Cedraschi, C. (2012). Psychological distress in fibromyalgia patients: A role for catechol-O-methyl-transferase Val158met polymorphism. Health Psychology, 31(2), 242. https://doi.org/10.1037/a0025223.

Fikri, N., \& Maesaroh, M. (2020). Asuhan Keperawatan Pada Tn. R dengan Gangguan Sistem Endokrin Akibat Diabetes Mellitus di Ruang X (Pangeran Soka) Rsud Gunung Jati Cirebon. Jurnal Akper Buntet: Jurnal Ilmiah Akper Buntet Pesantren Cirebon, 4(1).

Organization, W. H. (2011). WHO report on the global tobacco epidemic, 2011: warning about the dangers of tobacco. Geneva: World Health Organization.

Organization, W. H. (2015). Report of the 6th meeting of the WHO advisory group on integrated surveillance of antimicrobial resistance with AGISAR 5-year strategic framework to support implementation of the global action plan on antimicrobial resistance (2015-2019), 10-12 June 2015, Seoul, Republic of Korea.

Tengah, D. J. (2013). Profil Kesehatan Jawa Tengah Tahun 2017. Semarang: Dinas Provinsi Jawa Tengah.

Wulandini, P., Roza, A., \& Safitri, S. R. (2018). Efektifitas Terapi Asmaul Husna Terhadap Penurunan Skala Nyeri Pada Pasien Fraktur Di Rsud Provinsi Riau. Jurnal Endurance: Kajian Ilmiah Problema Kesehatan, 3(2), 375-382. http://doi.org/10.22216/jen.v3i2.3116

(C) 2021 by the authors. Submitted for possible open access publication under the terms and conditions of the Creative Commons Attribution (CC BY SA) license (https://creativecommons.org/licenses/by-sa/4.0/). 